\title{
Coloured plastic mulches: impact on soil properties and crop productivity
}

\author{
Getachew Amare* (iD and Bizuayehu Desta
}

\begin{abstract}
Mulches are materials applied in a soil surface for different roles and purposes. Plastic mulches with different colour have been developed and utilized in different crop production systems. Using coloured plastic mulches is mainly focused in modifying the radiation budget and decreasing the soil water loss. Besides, it helps to regulate soil temperature, water use efficiency, plant growth, yield, quality and weed and insect infestation. In this review, the knowledge and possible application of coloured plastic mulches, which can improve the soil physical properties, growth, yield, and quality crops has been reviewed and discussed. The role of coloured plastic mulches to mitigate the harmful effect of environmental stress in crops is also examined. Various physicochemical processes leading to improved crop production under the effect of coloured plastic mulches are also discussed. The combined results indicated that, effect of coloured plastic mulches is highly significant on soil temperature, moisture and water holding capacity. While black and blue plastics increase soil temperature, clear and white decreases it. Higher number of fruits, number of roots, tubers and bulbs was recorded in use of coloured plastic mulches. Similarly, the TSS, Vitamin C and juice percentage of different plants also showed significant improvement. It is also reported that weed infestation and viral diseases is highly reduced. Coloured plastic mulches also have some negative impacts like, decrease growth and yield in some plants, increase pest infestation, microplastics contamination, soil puddling, soil structural loss and reduce activity of soil-microorganisms. Therefore, use of coloured plastic mulches require close inspection of interaction with factors like; cropping season, root zone temperature, crop type, insect pest infestation and water use efficiency factors.
\end{abstract}

Keywords: Coloured plastic, Mulch, Pest, Quality, Soil, Yield

\section{Introduction}

A Germanic word 'mulch', which represents 'molsh' means soft. It doesn't mean all mulches are soft, but it represents a soft, spongy layer found in forest ecosystems. Other definitions also define mulches as materials applied to or grow upon, the soil surface [1]. Mulches have a significant effect in preventing drought stress, protection from freezing, improving soil chemical, physical, biological properties, disease control, and enhancing crop productivities [2-4].

Mulches utilized in the farming systems vary in type and characteristics. The most known mulches are gravel

\footnotetext{
*Correspondence: getchamare38@gmail.com

Department of Horticulture, College of Agriculture and Natural Resources

Sciences, Debre Berhan University, 445, Debre Berhan, Ethiopia
}

mulches, pebbles, polyethylene film, organic- straw, hyacinth, wood, bark, or leaves, used individually or in mixtures, or living- turf grass, rye, and clover materials [3-5]. Organic mulches mainly organic straws are the most common mulches utilized in developing countries. But, organic-mulches are subjected to decomposition, are less efficient, labour-intensive, and weather dependant [6].

The development of polyethylene (PE) as a plastic film in 1938 and its introduction as a plastic mulch for vegetable crop production in the 1950s significantly enhances commercial crop production [7]. The world plastic production in the year 2018 was 360 million tonnes with a distribution percentage of Asia 51\%, Europe 17\%, NAFTA (North American Free Trade Agreement) 18\%, Africa 7\%, CIS (Commonwealth of Independent States) 3\%, and Latin America 4\% [8]. From the plastics fabricated, 
agricultural production uses nearly $4 \%$ of it for different purposes, including mulching [8].

Regardless of their nature of the source of production, the plastics produced are polyethylene, polyamides, polypropylene, polycarbonate, expanded polystyrene, polyethylene terephthalate, etc. Various types of polyethylene coloured plastic mulches have been utilized in the farming community with different formulations for a different purpose. Previously black, clear, and white plastic mulches were utilized for vegetable farming. The plastic colours known today are mainly, Black, white, green, brown, red, silver, and blue. These colours are formulated with their role in light absorption and crop physiology. The impact of these coloured plastic mulches is quantified by many researchers in different crops [9-12].

Black plastic mulch is the most available and most used of others. It absorbs efficiently UV(Ultraviolet), visible, and infrared wavelengths of solar radiation released from the sun. It showed significant impact in increasing soil heat by absorbing high amount of radiation. White plastic mulch is the reverse of the black one. It cools the soil and mostly used in crops that require less soil heating $[7,10,13]$. Red plastic mulch is the most efficient in absorbing global solar radiation than black, blue, green, and yellow plastic mulches. Based on the order of global solar radiation transmittance, black $<$ blue $<$ yellow $<$ green $<$ red $<$ transparent plastic mulches [14]. There are also reports which describe the energy balance in the order of red $>$ transparent $>$ green $>$ blue $>$ yellow $>$ black [15]. The variation in that colour of plastic mulches is designed to alter the micro-climate at the plant and soil levels. Variation in colour of plastic mulches affect spectral balance, quality, and quantity of light that affects many plant growth and developmental patterns including the yield of plants [16].

Plastic mulches also directly affect the microclimate around the plant by modifying the radiation budget and decreasing the soil water loss. It enhances crop production by increasing fruit quality, gross yield, and earlier production [17]. To increase crop production and productivity, field evaluation has been done on new formulations of wavelength-selective, biodegradable, and coloured plastic mulches [18, 19].

Coloured plastic mulches also significantly affect light absorptivity, light reflectivity, soil water loss, soil temperature, plant morphology, and weed control [20]. The purpose of variation of colours to impact the absorption and reflection of FR: $\mathrm{R}$ (far-red to Red) ratios result in phytochrome regulation. Plants receiving high FR: $\mathrm{R}$ light responds in increased plant height and above-ground biomass $[20,21]$.

The main kinds of coloured plastic mulches used in different parts of the world for different crops are, black, white, and clear plastic mulches. Black plastic mulch used to increase light and temperature absorption, white to reflect, and clear one to produce large heat $[10,20]$. Recently, various plastic mulches with different colours and formulations have been developed. These coloured plastic mulches are used in the cropping system of different plants for different purposes. According to research reports different coloured plastic mulches impact crop production in different ways. Their level of impact is extended to the soil, water, and yield and quality of crops. Therefore, this review evaluates the impact of coloured plastic mulches on soil, light absorption, and crop yield and quality.

\section{Effect of coloured plastic mulches on soil temperature}

Any treatment or any technological application to enhance plant growth and development significantly affects the soil. The physical, chemical, and biological properties of soil were all affected by these technological inputs. Soil temperature is one of the main properties of soil which affects crop production. As expressed by different authors, systems and processes involved inside a soil mainly nutrient uptake, absorption of water root growth, and life of soil microorganisms depend on the level of soil temperature [22, 23].

Coloured plastic mulches significantly alter the soil temperature. Franquera [20] reported a higher soil temperature due to colored plastic mulches than bare soil. Their result indicated that blue plastic mulch contains more temperature than red. According to Farias-Larios and Orozco-Santos [24], the highest temperature was recorded by clear plastic mulch and there was no difference in temperature by black plastic mulch and bare soil. Similarly, the experiment by Gordon et al. [12] showed there is a difference in soil temperature by coloured plastic mulches and row cover. The highest temperature $\left(31.2{ }^{\circ} \mathrm{C}\right)$ was recorded by black plastic mulch with row cover and the lowest $\left(31.2^{\circ} \mathrm{C}\right)$ was recorded from bare soil.

The reported impact of coloured plastic mulches on soil temperature by different researchers is variable from area to area and from crop to crop. A research report by Shah Jahan et al. [25] indicated that higher temperature was recorded by black plastic mulches than olive, silver, white, and blue. But Ibarra-Jime'nez et al. [26] reported that brown and blue plastic mulches were higher in soil temperature than the other mulches including black. This variation will be due to variations in soil type and climatic conditions of the areas. Confirming this, reports indicated that black plastic mulch is efficient in increasing minimum, maximum, and mean soil temperature 
than white/black, aluminium/black plastic mulching systems [27].

Covering the land with black and white plastic mulch during the production period increases the soil temperature significantly. The increase in soil temperature could reach to $60^{\circ} \mathrm{C}$ by the trap of solar radiation in black and white plastic mulches. This increase in temperature specifically enhances weed suppression in weed-infested areas $[28,29]$. On other reports, higher temperature was examined in black and brown plastic mulches than white [30].

Black and white plastic mulches were tested for their role in overwintering by protecting from the injurious cold temperatures. Their effect was not as expected, both plastic mulches reduce the overwintering capacity of shrubs rather than increasing survival ability [31]. Further reports also indicate that, black and brown plastic mulches are reported effective in increasing root zone temperature (RTZ). Increasing the root zone temperature by plastic mulches is highly required in areas with cold climatic conditions but not in warm areas [32,33].

The temperature in the root zone decreased when the plant developed a full canopy. This event was recorded in tomato and radish plants. An increase in canopy increases shading on plastic mulch; this restricts direct interception of solar radiation and heat transfer from surrounding air and soil [34, 35]. It is eminent that using coloured plastic mulches enhance the temperature of the soil. There is a higher soil temperature by coloured plastic mulches than bare land. Any grower who intends to increase the soil temperature can use coloured plastic mulches. But, the decision on selecting the type of colours depends on the climate, soil type, crop type, and intended purpose.

\section{Effect of coloured plastic mulches on soil water and water use efficiency}

Water is one of the necessities of plants life in which all their processes during their lifecycle depends on. Inevitably, without water, living things are impossible to exist. The role of water in the plant's life is mainly on hydration, transpiration, and dry matter production of plants [36]. Decreasing water loss and irrigating to the level of optimum water availability enhances plant growth, development, and yield.

Many technologies were tested to enhance the availability of water for plants and to protect water loss. It is verified that mulches enhance the availability of water for plants by their impact on reducing erosion, evaporation, surface temperature, wind impact, and weed infestation [37-39]. Different researchers reported that coloured plastic mulches have a visible impact on effective water use, protection against water loss, and enhancing water use efficiency for different crops [15, 25, 39, 40].

As Water use efficiency is the new way of agriculture, its focus is in increased production by a limited amount of water. In arid and semi-arid areas, it is critical to saving water and enhancing crop productivity. Crop yield is linearly related with the available water and water use efficiency in the production period [41]. Mostly non mulched land shows higher water loss than the plastic covered lands. This is because there is an increase in exposure to water loss agents, mainly solar radiation, wind, and heat [42]. Plastic mulching shows a positive impact on yield and water use efficiency of plants than conventional tillage patterns. It was reported that black and white plastic mulching increases water use efficiency in potato plant by $31 \%$ than non-mulched land [43].

Efficiency in water use was reported to be improved thorough the use of black plastic mulches. Such efficiency is attained because of its impact in reduction of evapotranspiration from the soil surface. This signifies the role of black plastic mulch in reducing moisture loss, in enhancing protected agriculture and decreasing the plant requirement for higher irrigation water [44, 45]. But, comparison between black and white plastic mulches verified that the rate of evapotranspiration by black plastic mulch (202-442.6 mm), is higher than white plastic mulching $(142.8-436.1 \mathrm{~mm})$ [43]. In addition, early researches indicated that covering by black plastic mulch enhances the availability of moisture but less than straw and organic mulches. Whereas, under high rainfall, black plastic mulches are preferable than both organic and other coloured plastic mulches [46, 47].

Trapping black plastic mulches on the soil to modify the environment around it, is one of the common practices in farming community. Such trapping increases the water holding capacity of the soil, and enhance the nitrate in it. Besides, this practice can also improve the ability to hold moisture in reduced tillage production systems [48].

Photosynthetically active radiation (PAR) is mainly affected by the colours of plastic mulches. The variation in the colours of the plastic mulches will increase or decrease the transmittance, absorbance, and reflectance of both short wave and long wave radiations which affects PAR. Higher reflection in PAR creates a lower amount of soil temperature and higher moisture content in the root zone of the plants. Silver plastic mulches are higher in reflecting PAR than black and white plastic mulches. Such higher reflection of PAR by silver plastic mulches reduces root zone temperature and loss of water [48-50]. These important characteristics of this plastic mulch makes it efficient in conserving water and protecting water loss [48-51]. 
Increase in water use efficiency of wheat, maize, and potato plants has been reported using plastic mulch [52, 53]. This role could be associated with impact of plastic mulches on decreasing soil bulk density, increase soil porosity, and enhancing nutrient contents [54]. Furthermore, it decreases soil evaporation, enhances soil water infiltration, redistributes soil moisture, and relieve water stress $[55,56]$.

The impact of plastic mulches was also expressed by the index of water-use efficiency under black, yellow, and transparent plastic mulches as $7.76,8.34$, and $8.51 \mathrm{~kg} \mathrm{~m}^{-3}$ above $160 \%$ higher than the non-mulched [57]. In bell paper, the use of plastic mulches resulted in 33 to $52 \%$ more efficient use of irrigation water than un-mulched lands [58].

In some methods of plastic mulching, even if it is effective in providing improved moisture within the soil, its impact in the plant's microclimate (root zone temperature and heat retention) impacts more water use, thus negating the initial importance in moisture conservation $[55,69]$.

\section{Effect of coloured plastic mulches on plant growth and development}

The growth and development of crops are affected by many environmental and edaphic factors. To modify the impact of these factors, various methods have been developed. Plastic mulches are ubiquitously utilized and are reported to enhance the growth and development of shrubs, vegetables, and other crops [45, 47, 59-62].

According to research on plastic mulches, white plastic mulches activated earlier branching with the expense of shortened height of the plant than plants grown on black plastic mulches [63]. Coloured plastic mulches as a row cover reportedly increased the leaf area of watermelon and potato plants. Similarly, it is verified that black and silver plastics are effective in an increase of leaf area than bare land. The positive impact of these plastic mulches in enhancing leaf area would increase the rate of photosynthesis, plant yield, and quality [64-66].

In radish plant, transparent and green mulches alter an increase in growth and development of root (length, diameter, weight) and leaf weight compared to those in bare soil. In Sincheongilpum variety highest length $(21.7 \mathrm{~cm})$, diameter $(6.6 \mathrm{~cm})$ and weight $(810 \mathrm{~g})$ was recorded by black plastic mulch. Whereas, Bordeaux variety all root and leaf parameters were higher in bare soil than plastic mulched treatments. This indicated that there is a varietal difference in response to plastic mulch use [35].

In lettuce highest number of leaves, longleaf, and higher leaf width was noted by black polyethylene, followed by white, blue, silver, and olive film [25]. Such enhanced growth and development of plants by coloured

Table 1 Effect of coloured plastic mulches on growth and yield of crops

\begin{tabular}{|c|c|c|c|c|}
\hline Author & Crop type & Colour of plastic mulch & Effect on Growth & Yield \\
\hline Lee and Park [35] & Radish & Transparent plastic mulch & $\begin{array}{l}\text { Highly significant on root length, } \\
\text { root diameter, and root weight for }\end{array}$ & \\
\hline Lee et al. [80] & Onion & Transparent plastic mulch & $\begin{array}{l}\text { Higher number of leaves and plant } \\
\text { height }\end{array}$ & $\begin{array}{l}\text { Increased bulb diameter and bulb } \\
\text { weight }\end{array}$ \\
\hline Li et al. [3] & Potato & Black plastic mulch & & Yield higher than un-mulched land \\
\hline Torres-Olivar et al. [81] & Onion & Silver/black polythene film & $\begin{array}{l}\text { Higher plant height, leaf area, shoot } \\
\text { dry weight }\end{array}$ & High yield than black and white/black \\
\hline Shah Jahan et al. [25] & lettuce & Black plastic mulch & & $\begin{array}{l}\text { Higher yield than blue, white, and } \\
\text { un-mulched }\end{array}$ \\
\hline Sarkar et al. [5] & lettuce & Silver and black plastic mulch & $\begin{array}{l}\text { Silver polyethene mulch-higher } \\
\text { plant height and number of leaves } \\
\text { Black polyethene film-higher root } \\
\text { length }\end{array}$ & $\begin{array}{l}\text { Silver polyethene film- higher bulb } \\
\text { length, diameter, and biomass than } \\
\text { black and un-mulched land }\end{array}$ \\
\hline Franquera and Mabesa [70] & Lettuce & Red plastic mulch & & $\begin{array}{l}\text { Higher yield was recorded than silver } \\
\text { plastic mulch }\end{array}$ \\
\hline Torres-Olivar et al. [69] & cucumber & Red, Black, Blue, White & $\begin{array}{l}\text { Red and black plastic mulches } \\
\text { increase shoot dry biomass and } \\
\text { leaf area }\end{array}$ & $\begin{array}{l}\text { No significant differences between } \\
\text { the colour of mulches }\end{array}$ \\
\hline Filipović et al. [82] & Bell paper & Black and brown plastic mulch & $\begin{array}{l}\text { Higher plant height, number of } \\
\text { flowers recorded by black and } \\
\text { brown than silver and white }\end{array}$ & $\begin{array}{l}\text { Higher plant yield recorded by black } \\
\text { and brown than silver and white. }\end{array}$ \\
\hline Ruíz-Machuca et al. [66] & Potato & $\begin{array}{l}\text { Black, White/black, and Silver/ } \\
\text { white row covers }\end{array}$ & $\begin{array}{l}\text { Higher leaf area and plant dry } \\
\text { weight was recorded }\end{array}$ & $\begin{array}{l}\text { Higher yield was recorded by black } \\
\text { followed by White/black and Silver/ } \\
\text { white }\end{array}$ \\
\hline
\end{tabular}


plastic mulches is by its impact on creating an optimum growth environment like adequate moisture and root zone temperature. It was also noted that improving the micro-climate around plants using coloured plastic mulching increases cell expansion and elongation which can increase the growth and development of plants [67, 68].

In onion, different growth characteristics were observed by different coloured plastic mulching (Table 1). Higher plant height, number of leaves, and fresh root biomass were observed by silver mulching, whereas, the highest root length was recorded by black plastic mulching than the silver ones [5]. The growth characters of plants mainly stem diameter, plant height, leaf length, leaf dry weight, stem dry weight, and plant dry weight were reported to be affected by the mean soil temperature. As indicated by some reports, use of coloured plastic mulch creates a positive relationship between mean soil temperature and growth characters [15, 69-71], and others reported a negative relationship [52]. As for research results, even if the impact varied from crop to crop, use of coloured plastic mulches increase the growth and development of plants (Table 1). From those reports black plastic mulch is repeatedly reported in enhancing growth and development of plants.

\section{Effect of coloured plastic mulches on yield of plants}

Among the soil characteristics, soil temperature around the roots zone (root zone temperature) affects the physiology of plants. Root zone temperature mainly affects plant growth, root development, aeration, water, and mineral uptake. The impact of root zone temperature on such soil characteristics significantly affects the yield of plants [72, 73].

On the pepper plant, the fruit yield is significantly affected by the colours of plastic mulches and atmospheric conditions across seasons. In hot season the yield by silver plastic film mulching was higher than black plastic film, but, in the cool climatic condition, the reverse happens [51]. Across two seasons, the highest number of fruits per plant ( 8 fruits/plant) was recorded by silver plastic with black strip mulch. Whereas, the highest weight of fruit per plant $(1 \mathrm{~kg})$ was recorded by silver plastic mulch. Black plastic mulch is reported as effective in increasing the yield of black currant plants by maintaining the soil condition and restricting weed growth. The average yield for 6 years was 26\% higher where black plastic mulch was used ( $712 \mathrm{~g}$ per plant) compared to no mulch (565 g per plant) [60, 74].

The yield capacity of shrubs like hyssop, garden thyme, lemon balm, and coneflower were reported to be affected by the plastic mulching. The highest yield was observed by black plastic, the lowest by white plastic mulch and non-mulched lands [30]. On the contrary, other reports indicated that the yield of thyme was low by black plastic mulch as compared to non-mulched lands [75].

It was indicated that chili plants grown in the black plastic film showed the highest amount of chlorophyll a and $b$, total chlorophyll contents, the highest number of fruits, and increased yield [76]. Such difference in chlorophyll content due to coloured plastic mulching is associated with the spectral distribution of light reflected from the colour of the film $[77,78]$. This increase in chlorophyll content influences the rate of photosynthesis, production of assimilates which can increase the yield of plants.

Even if coloured plastic mulches had a positive impact on the yield of plants it is variable with colour and the mean air temperature of the growing season and area. In potato plant when the mean air temperature was higher than $20{ }^{\circ} \mathrm{C}$ the yield by black plastic mulch was higher than white plastic mulch and below this temperature higher yield was recorded by white plastic film. The result indicated that, the yield of potato plant increased by $29.2 \%$ by plastic mulches than bare land [3]. In wheat and maize plants, plastic mulching significantly increased the yield of the plants. In wheat, the increase was $20 \%$ and in maize plants the yield increment is $60 \%$ higher by use of plastic mulching [53].

The yield of plants is directly related to the growth and development performance of crops. Hence, in most plants the increase in yield was recorded by use of plastic mulches (Table 1). This impact is associated with the impact of plastic mulching on improvement of the microclimate and root zone temperature of plants which increases activities of cell expansion and cell enlargement. Furthermore, the active involvement of the enzymes in enhancing growth development also increased the yield of plants $[67,79]$.

\section{Effect of coloured plastic mulches on quality of produces} Watermelon plants covered by black plastic mulch showed an increase in dry matter percentage, total and reducing sugars, and vitamin $C$ contents [57]. Similarly, black plastic mulch is effective in increasing the vitamin $\mathrm{C}$ and phenolics content of the lettuce plants. Further reports also indicated that the impact of black plastic mulch in improving quality parameters is higher than bare land production system [25, 83]. But, in contrary to this, other reports indicated, there is lower vitamin $\mathrm{C}$, tuber firmness, specific gravity, and starch content of potato by coloured plastic mulching [84, 85].

Coloured plastic mulches affect the biochemical composition of plastic mulches. Onion crops grown by silver polyethylene film exhibited an increase in the content of total soluble solids, reducing sugar, non-reducing sugar, vitamin $\mathrm{C}$, and pyruvates. Researchers associated 
this factor with the potential of coloured plastic films in reflecting light influences the microbial activity in enhancing $S$ and K activity photosynthesis [5, 86].

Black plastic mulch reported influencing the quality parameters of strawberry and beet grown under different agroecology. The highest amount of sugar, vitamin C, TSS, and juice percentage was observed by black mulches than other mulch types [76, 87].

Regarding quality enhancement by polyethylene mulches, reports explained the impact is associated with the higher water use efficiency, nutrient availability, higher root activities including higher uptake of water and nutrients, high rate of photosynthesis, and other enzymatic activities [12, 68, 88-91].

\section{Effect of coloured plastic mulches on weed, diseases and insect pest control}

Weed suppression is reported as one of the positive impacts of plastic mulching. Mulching by its effect on shading, which reduced germination and seedling growth of weeds; and by acting as a physical barrier reduced weeds' existence [61]. Weed control has been practiced in crop farming systems by temporary, impermeable, black plastic tarps, solarization plastic covers, and long use plastic mulches [60, 92].

Better plant performance and less weed biomass were reported by coloured plastic mulching on a ginger plant than non-mulched lands. But according to this report, the impact of plastic mulches on reducing weed infestations and yield of the plant were lower than organic mulches like coconut leaves [6]. Other reports found that plastic mulch reduced weed dry matter by $63.8 \%$ compared with an un-mulched land [71] and black plastic mulch showed decreased weed dry weights by $91.3 \%$ and 94.7\% [61].

On contrary to positive impact, reports indicated that plastic mulch increased insect pest attacks in some crops. In addition, black plastic film (lower PAR reflection) and silver plastic mulch (high Par reflection) also resulted in a non-significant difference to non-mulched lands in thrips and tomatoes spotted wilt infestation [51]. Similarly, bacterial soft rot (Erwina spp) incidence exhibited an increase in plants covered by black plastic mulch [93].

Positive result was reported about the impact of black and clear plastic mulches in reducing weed infestation. This impact is a factor of their effectiveness at warming the soil and increasing root zone temperature. But the impact of black plastic mulch on reducing weed competition is better than clear plastic mulch as it lays across the soil and around the crop reduce the light reaching the soil. This inhibits the level of effectiveness of weed germination and smothers emerging weeds [94, 95].
Aphids are one of the crop pests severely affected by plastic mulching. Clear plastic mulch is reported as highly effective in repelling this pest than black plastic and bare-root production [96]. On contrary to this, other reports also verified that, yellow plastic mulch have a negative impact on insect pest control. It attracts green pea aphids (Myzus persicae), striped (Diabrotica undecimpunctata) and spotted (Acalymma trivitatum) cucumber beetles [79, 97].

But, according to other reports, among coloured plastic mulches, white and clear are effective in reducing the incidence of viral diseases, whitefly population, and aphid population. In some crops repelling aphids reduces viral disease incidence $[98,99]$. It was also reported that the infestation by thrips was reported as low in red, green, and black plastic mulches [100]. Therefore, from all the reports, there is a clear difference in the role of plastic mulches in reducing pest and diseases impact. But black and clear plastic mulches exhibited a positive impact in reducing pest and diseases attack in most crops $[98,99]$.

\section{Drawbacks and damaging effect of coloured plastic mulches}

Agricultural practices by coloured plastic mulches could be one of the major agents in terrestrial microplastic contamination [101, 102]. The projected increase in the use of plastic mulches for agriculture production is expected to grow at $5.6 \%$ per year through 2030 . This increased rate indicates there will be further contamination of arable land by plastic mulching [103]. Microplastics retained from coloured plastic mulching negatively affect the activity of soil microorganisms [104], soil structure, soil chemical property [105], and plant performance [106].

Plastic mulch production is also labour-intensive, require special equipment, costly as it incurs further cost in removal and disposal after the production period [107]. From the farmer's perspective, the cost for removal will not be appreciated and if there are remains left it can cause puddling and structural destruction on soils.

Furthermore, producing by black plastic mulch in hot climatic conditions may contribute to the high temperatures around the root zone. If the root zone temperature is above average, the growth of the plant will be curtailed significantly $[25,40]$. Other investigations also revealed that the use of plastic mulch increases diseases and insect pest attacks in some crops. Polyethylene plastic mulches also create soil puddling, soil erosion, and reduced water holding capacity. In addition, use of coloured plastic mulches will impact the soil microbiota and will negate the natural functioning of terrestrial ecosystems by its direct and indirect impact on soil health [86, 108].

It is known that soil microorganisms are important in soil systems mainly biodegradation and biochemical 
cycling. Soil microbes are mainly dependant on the nature and properties of soil classes. Plastic mulches utilized in the farming system litter microplastics in the soil zone. The negative impact of these ruminants of the plastic is on soil aeration, physical and chemical properties. The puddling and physical loss of soil are detrimental to soil biota mainly soil microorganisms [105, 108]. Hence even if use of coloured plastic mulches has positive impact in increasing crop yield and quality, care should be taken in amount, type, and rate of use of plastic mulches.

\section{Conclusion}

In arid and semi-arid environments of the tropics and subtropics, moisture, temperature, precipitation, and other soil factors are the limiting factors in crop production. Lower root zone temperature, high rate of evaporation, and insufficient rainfall determine cropping systems. Using coloured plastic mulches is widely accepted and utilized in the farming community to solve above-lined problems. It is indicated that coloured plastic films affect the plant root zone temperature, microbial life, soil properties, and moisture levels. By improving the plant microclimate, coloured plastic mulches increase plant growth, development, quality, and yield of most crops. Black and silver-coloured plastic mulches are reported to enhance growth, yield, and quality in most crops than other coloured mulches. In some crops, even if there are beneficial roles by coloured plastic mulches, its use also exhibited a negative effect on yield and insect pest control. In addition, the fragments of plastic mulches pollute the arable land significantly. Therefore, even if the use of plastic mulch increases yield, quality of crop production, its use requires close inspection of factors like; cropping season/mulch interaction, root zone temperature/mulch interaction, the colour of plastic mulch/crop interaction, coloured plastic mulch/insect pest interaction and crop type/water use efficiency factors.

\section{Abbreviations}

CIS: Commonwealth of Independent States; FRR: Far red to red; NAFTA: North American Free Trade Agreement; PAR: Photosynthetically active radiation; RTZ: Root zone temperature; TSS: Total soluble solids; UV: Ultraviolet.

\section{Acknowledgements}

We acknowledge horticulture department of Debre Berhan university.

\section{Authors' contributions}

GAK is the first author of the review article, whereas the co-authors have contributed equally for the literature collection, manuscript documentation and its revision. Both authors read and approved the final manuscript.

\section{Funding}

There is no funding granted.
Availability of data and materials

Not applicable.

Ethics approval and consent to participate

It is not applicable.

\section{Consent for publication}

The authors confirm that the content of the manuscript has not been published, or submitted for publication elsewhere.

\section{Competing interests}

There are no competing interests between authors.

Received: 26 August 2020 Accepted: 24 November 2020

Published online: 19 January 2021

\section{References}

1. Chalker-Scott Linda. Impact of mulches on landscape plants and the environment. PJ Environ Hort. 2007;25:239-49.

2. Cahill A, Chalker-Scott L. Wood-chip mulch improves plant survival and establishment at no-maintenance restoration site (Washington). Ecol Restor. 2005:23:212-3.

3. Li Q, Li H, Zhang L, Zhang S, Chen Y. Mulching improves yield and water-use efficiency of potato cropping in China: a meta-analysis. F Crop Res. 2018;221:50-60.

4. Franquera EN. Effects of plastic mulch color on the total soluble solids, total sugars and chlorophyll content of lettuce (Lactuca sativa L). Int J Res Agric For. 2015;2:18-24.

5. Sarkar MD, Solaiman AHM, Jahan MS, Rojoni RN, Kabir K, Hasanuzzaman M. Soil parameters, onion growth, physiology, biochemical and mineral nutrient composition in response to colored polythene film mulches. Ann Agric Sci. 2019;64:63-70.

6. Thankamani CK, Kandiannan K, Hamza S, Saji KV. Effect of mulches on weed suppression and yield of ginger (Zingiber officinale Roscoe). Sci Hortic (Amsterdam). 2016;207:125-30.

7. Lamont WJ. Plastic mulches for the production of vegetable crops. A Guid to Manuf Performance. Potential Plast Agric. 2017. https://doi. org/10.1016/b978-0-08-102170-5.00003-8.

8. Plastics Europe (PEMRG). Plastics. Brussels. Ramos. 2019.

9. Rajablariani HR, Hassankhan F, Rafezi R. Effect of colored plastic mulches on yield of tomato and weed biomass. Int J Environ Sci Dev. 2012;3:590-3.

10. Decoteau DR. Mulch surface color affects yield of fresh-market tomatoes. J Amer Soc Hort Sci. 1989;114:216-9.

11. Alizadeh A. Study of changes in soil moisture and salinity under plasticmulch and drip irrigation in pistachio trees. J Nuts. 2016;7:21-33.

12. Gordon GG, Foshee WG, Reed ST, Brown JE, Vinson EL. The effects of colored plastic mulches and row covers on the growth and yield of okra. Horttechnology. 2010;20:224-33.

13. Cooperating USD of A Mulch: using colored plastic mulches in the vegetable garden. p. 1-2.

14. Al-Karaghouli A, Al-Kayssi AW, Hasson AM. The photometric properties of different colored plastic mulches used for soil solarization. Sol Wind Technol. 1990;7:119-23.

15. Alkayssi AW, Alkaraghouli AA. Influence of different colour plastic mulches used for soil solarization on the effectiveness of soil heating. Soil solarization (Eds JE Vay, JJ Staplet CL Elmore). FAO Plant Prod Prot Pap. 1991; 109:297-308.

16. Matsoukis A, Gasparatos DCSA. Impact of shading and chlormequat chloride on lantana specific leaf area and mineral content. J Anim Plant Sci. 2015;25:1371-6.

17. Díaz-Pérez JC. Root zone temperature, plant growth and yield of broccoli [Brassica oleracea (Plenck) var. italica] as affected by plastic film mulches. Sci Hortic (Amsterdam). 2009;123:156-63.

18. Berger S, Kim Y, Kettering J, Gebauer G. Plastic mulching in agricultureFriend or foe of N2O emissions. Agric Ecosyst Environ. 2013;167:43-51.

19. Khan VA, Decoteau DR, Building T. The emergence and early development of colored reflective plastic mulch technology in agriculture. J Nutr. 2008;661:1-17. 
20. Franquera EN. Influence of different colored plastic mulch on the growth of lettuce (Lactuca sativa). J Ornam Hortic Plants. 2011;1:97-104

21. Fortnum BA, Decoteau DR, Kasperbauer MJ, Bridges W. Effect of colored mulchs on root-knot of tomato. Phytopathology. 1995;85:312-5.

22. Kaspar TC, Bland WL. Soil temperature and root growth. Soil Sci. 1992;154:290-9.

23. Sabri NSA, Zakaria Z, Mohamad SE, Jaafar AB, Hara H. Importance of soil temperature for the growth of temperate crops under a tropical climate and functional role of soil microbial diversity. Microbes Environ. 2018;33:144-50.

24. Farias-Larios J, Orozco-Santos M. Effect of polyethylene mulch colour on aphid populations, soil temperature, fruit quality, and yield of watermelon under tropical conditions. New Zeal J Crop Hortic Sci. 1997;25:369-74

25. Shah Jahan M, Sarkar DM, Chakraborty R, Muhammad Solaiman AH, Akter A, Shu S, Guo S. Impacts of plastic filming on growth environment, yield parameters and quality attributes of lettuce. Not Sci Biol. 2018;10:522-9.

26. Ibarra-Jiménez L, Zermeño-González A, Munguía-Lopez J, Rosario Quezada-Martín MA, De La Rosa-Ibarra M. Photosynthesis, soil temperature and yield of cucumber as affected by colored plastic mulch. Acta Agric Scand Sect B Soil Plant Sci. 2008;58:372-8.

27. Canul-Tun CE, Ibarra-Jiménez L, Valdez-Aguilar LA, Lozano-del Río AJ, Cárdenas-Flores A, Zermeño-González A, Lozano-Cavazos CJ, Valenzuela-Soto JH, Torres-Olivar V. Influence of colored plastic mulch on soil temperature, growth, nutrimental status, and yield of bell pepper under shade house conditions. J Plant Nutr. 2017;40:1083-90.

28. Abu-Gharbieh, Saleh WI, Abu-Blan H. Use of black plastic for soil solarization and post-plant mulching. FAO Plant Prod. Prot. Pap. 109. Plant Prot. Dept., Fac. Of Agr., Univ. of Jordan, Amman, Jordan. 1988.

29. Egley $\mathrm{G}$. Weed seed and seedling reductions by soil solarization with transparent polyethylene. Weed Sci. 1983:31:404-9.

30. Taylor P, Aziz N, Sauve RJ, Long D, Cherry M. Genetic and phytochemical diversity assessment among eleven hypericum accessions via AFLP and HPLC Analyses Genetic and Phytochemical Diversity Assessment Among Eleven Hypericum Accessions via AFLP and HPLC Analyses. J Herbs Spices Med Plants. 2008;2:37-41.

31. Galambosi G, Szebeni-Galambosi ZS. The use of black mulch and ridges in the production of herbicide free herbs. Acta Hortic. 1992;306:353-6.

32. Orozco FJ, Guzman M, Aguilar S. Soil temperature and moisture under different plastic mulches and their relation to growth and cucumber yield in trop- ical regions. Gartenbauwissenschaft. 1994;59:249-52.

33. Palada MC, Crossman SMA, Kowalski JA, Collingwood DC. Evaluation of organic and synthetic mulches for basil production under drip irrigation. J Herbs Spices Med Plants. 1999;6:39-48.

34. Díaz-Pérez JC, Gitaitis R, Mandal B. Effects of plastic mulches on root zone temperature and on the manifestation of tomato spotted wilt symptoms and yield of tomato. Sci Hortic. 2007;114:90-5.

35. Lee ON, Park HY. Effects of different colored film mulches on the growth and bolting time of radish (Raphanus sativus L). Sci Hortic (Amsterdam). 2020;266:109271.

36. Neil Turner C, Gordon Burch J. The role of water in plants. 1978.

37. Döring TF, Brandt M, Heß J, Finckh MR, Saucke H. Effects of straw mulch on soil nitrate dynamics, weeds, yield and soil erosion in organically grown potatoes. F Crop Res. 2005;94:238-49.

38. Niziolomski JC, Simmons RW, Jane Rickson R, Hann MJ. Efficacy of mulch and tillage options to reduce runoff and soil loss from asparagus interrows. CATENA. 2020;191:104557.

39. Bucki P, Siwek P. Organic and non-organic mulches - Impact on environmental conditions, yield, and quality of Cucurbitaceae. Folia Hortic. 2019;31:129-45.

40. Onwuka B. Effects of soil temperature on some soil properties and plant growth. Adv Plants Agric Res. 2018;6(3):89-93. https://doi.org/10.15406/ apar.2018.08.00288.

41. Zhong Y, Shangguan Z. Water consumption characteristics and water use efficiency of winter wheat under long-term nitrogen fertilization regimes in northwest China. PLoS One. 2014. https://doi.org/10.1371/ journal.pone.0098850.
42. Snyder K, Grant A, Murray H, Wolff B. The effects of plastic mulch systems on soil: temperature and moisture in central Ontario. Horttechnology. 2015;25:162-70.

43. Li Q, Li H, Zhang S. Yield and water use efficiency of dryland potato in response to plastic film mulching on the Loess Plateau. Acta Agric Scand Sect B Soil Plant Sci. 2018;68:175-88.

44. Alenazi M, Abdel-Razzak H, Ibrahim A, Wahb-Allah M, Alsadon A. Response of muskmelon cultivars to plastic mulch and irrigation regimes under greenhouse conditions. J Anim Plant Sci. 2015:25:1398-410.

45. Palada MC, Crossman SMA, Kowalski JA, Collingwood CD. Evaluation of organic and synthetic mulches for basil production under drip irrigation. J Herbs Spices Med Plants. 2000;6:39-48.

46. Schonbeck X. Effect of mulches on soil properties and tomato production. J Sustain Agric. 1998;13:1

47. Van Derwerken JE, Wilcox-Lee D. Influence of plastic mulch and type and frequency of irrigation on growth and yield of bell pepper. Am Soc Hortic Sci. 1988;23:985-8.

48. Rylander H, Rangarajan A, Maher RM, Hutton MG, Rowley NW, McGrath MT, Sexton ZF. Black plastic tarps advance organic reduced tillage ii: impact on weeds and beet yield. HortScience. 2020;55:1-6.

49. Lamont JW. Plastic mulches for the pro- duction of vegetable crops. Horttechnology. 1993;3:35-9.

50. Zhang YC, Han JH, Kim GN. Biodegradable mulch film made of starchcoated paper and its effectiveness on tempera- ture and moisture content of soil. CommunSoil Sci Plant Anal. 2008;39:1026-40.

51. Díaz-Pérez JC. Bell pepper (Capsicum annum L) grown on plastic film mulches: Effects on crop microenvironment, physiological attributes, and fruit yield. HortScience. 2010;45:1196-204.

52. Qin SH, Zhang JL, Dai HL, Wang D, Huang J. Effect of ridge-furrow and plastic-mulching planting patterns on yield for-mation and water movement of potato in a semi-arid area. Agric Water Manag. 2014;131:87-94.

53. Qin SH, Zhang JL, Dai HL, Wang D, Li DM. Soil mulching significantly enhances yields and water and nitrogen use efficiencies of maize and wheat: a meta-analysis. Sci Rep. 2015;131:9.

54. Hou F, Zhang L, Xie B, Dong S, Zhang H, Li A, Wang Q. Effect of plastic mulching on the photosynthetic capacity, endogenous hormones and root yield of summer-sown sweet potato (Ipomoea batatas (L) Lam) in Northern China. Acta Physiol Plant. 2015;37:1-10.

55. Zhao H, Wang RY, Ma BL, Xiong YC, Qiang SC, Wang CL, Liu CA, Li FM. Ridge-furrow with full plastic film mulching improves water use efficiency and tuber yields of potato in a semiarid rainfed ecosystem. $F$ Crop Res. 2014;161:137-48.

56. Xiao G, Zhang F, Qiu Z, Yao Y, Wang R, Huang J. Response to climate change for potato water use efficiency in semi- arid areas of China. Agric Water Manag. 2013;127:119-23.

57. El-Shaikh A, Fouda T. Effect of different mulching types on soil temperature and cucumber production under Libyan conditions. Misr J Agric Eng. 2008;25:160-75.

58. Palada MC, Davis AM, Kowalski JA, Crossman SMA. Yield and irrigation water use of vegetables grown with plastic and straw mulch in the US Virgin Islands. Int Water Irrig. 2003;23:21-5.

59. Clark JR, Moore JN. Southern Highbush Blueberry Response to Mulch. Horttechnology. 2018;1:52-4.

60. Dale A. Black plastic mulch and between-row cultivation increase black currant yields. Horttechnology. 2000;10:307-8.

61. Rajablarijani HR, Mirshekari B, AghaAlikhani M, Rashidi V, Farahvash F. Sweet corn weed control and yields in response to sowing date and cropping systems. HortScience. 2014;49:289-93.

62. Leskovar DI, Xu C, Agehara S. Planting configuration and plasticulture effects on growth, physiology, and yield of globe artichoke. HortScience. 2013;48:1496-501.

63. Decoteau DR, Kasperbauer MJ, Daniels DD, Hunt PG. Plastic mulch color effects on reflected light and tomato plant growth. Sci Hort. 1988:34:169-75.

64. Jenni S, Cloutier DD, Bourgeois G, Stewart K. A heat unit model to predict growth and development of muskmelon to anthesis of perfect flowers. J Am Soc Hortic Sci. 1996;121:274-80. 
65. Arancibia RA, Motsenbocker CE Differential watermelon fruit size distribution in response to plastic mulch and spunbonded polyester rowcover. Horttechnology. 2008;18:45-52.

66. Ruíz-Machuca LM, Ibarra-Jiménez L, Valdez-Aguilar LA, Robledo-Torres $V$, Benavides-Mendoza A, Fuente M. Cultivation of potato - use of plastic mulch and row covers on soil temperature, growth, nutrient status, and yield. Acta Agric Scand Sect B Soil Plant Sci. 2015;65:30-5.

67. Li FM, Wang J, Xu JZ, Xu HL. Productivity and soil response to plastic film mulching durations for spring wheat on entisols in the semiarid Loess Plateau of China. Soil Tillage Res. 2004;78:9-20.

68. Franquera EN. Effect of plastic mulch color on fresh weight of leaf lettuce (Lactuca sativa L) and soil carbon dioxide. Int J Innov Res Dev. 2015;4:1.

69. Torres-Olivar V, Valdez-Aguilar LA, Cárdenas-Flores A, Lira-Saldivar H, Hernández-Suárez M, Luis IJ. Effect of colored plastic mulch on growth, yield and nutrient status in cucumber under shade house and open field conditions. J Plant Nutr. 2016:39:2144-52.

70. Franquera EN, Mabesa RC. Colored plastic mulch effects on the yield of lettuce (Lactuca sativa L) and soil temperature. J Adv Agric Technol. 2016;3:155-9.

71. Mahajan G, Sharda R, Kumar A, Singh B. Effect of plastic mulch on economizing irrigation water and weed control in baby corn sown by different methods. Afr J Agr Res. 2007;2:19-26.

72. Tindall JA, Mills HA, Radcliffe DE. The effect of root zone temperature on nutrient uptake of tomato. J Plant Nutr. 1990;13:939-56.

73. Dodd IC, He J, Turnbull CGN, Lee SK, Critchley C. The influence of supra- optimal root-zone temperatures on growth and stomatal conductance in Capsicum annuum L. J Expt Bot. 2000:51:239-48.

74. Le GuiheneufY. paillage plastique en arboriculture fruitiere. Fruit Belge. 1988;56:66-72.

75. Collingwood CD, Crossman S. Response of selected herbs to improved production practices. Proc Caribb Food Crop Soc. 1991;27:159-64.

76. Ashrafuzzaman M, Halim MA, Ismail MR, Shahidullah SM, Alamgir HM. Effect of plastic mulch on growth and yield of chilli (Capsicum annuum L.) Brazilian Arch Biol Technol. 2011;54:321-30.

77. Chu Z, Tong Z, Feng L, Zhang Q, Wen X, Song S, Zhu X. Effect of different light quality on photosynthetic characteristics of cucumber leaves. Acta Bot Sin. 1999:41:867-70.

78. El-Yazied AA, Mady M. Plastic mulch color and potassiumfoliar application affect growth and productivity of strawberry (Fragaria X ananassa Duch). J Appl Sci Res. 2012;8:1227-39.

79. BraultD. The optical properties of paper and polyethylene mulches and their effect on growth and development of head lettuce (Lactuca Sativa L.), on microclimate modification and weed control in organic soil. McGill Univ. 2001

80. Lee J, Min B, Kim H, Kim J, Kwon YS, Boyhan GE. Effects of nonwoven polypropylene covering during overwintering on growth and bulb yield of intermediate-day onion. HortScience. 2019;54:303-10.

81. Torres-Olivar V, Ibarra-Jiménez L, Cárdenas-Flores A, Lira-Saldivar RH, Valenzuela-Soto JH, Castillo-Campohermoso MA. Changes induced by plastic film mulches on soil temperature and their relevance in growth and fruit yield of pickling cucumber. Acta Agric Scand Sect B Soil Plant Sci. 2018;68:97-103.

82. Filipović V, Romić D, Romić M, Borošić J, Filipović L, Mallmann FJK, Robinson DA. Plastic mulch and nitrogen fertigation in growing vegetables modify soil temperature, water and nitrate dynamics: experimental results and a modeling study. Agric Water Manag. 2016;176:100-10.

83. Kim BS, Lee HO, Kim JY, Kwon KH, Cha HS, Kim JH. An effect of light emitting diode (LED) irradiation treatment on the amplification of functional components of immature strawberry. Hortic Environ Biotechnol. 2011;2:35-9.

84. Wang FX., WummXX, Shock CC, Chu LY, Gu XX, Xue X. Effects of drip irrigation regimes on potato tuber yield and quality under plastic mulch in arid Northwestern China. F Crop Res. 2011;122:78-84.

85. Zhang YL, Wang FX, Shock CC, Yang KJ, Kang SZ, Qin JT, Li SE. Influence of different plastic film mulches and wetted soil percentages on potato grown under drip irrigation. Agric Water Manag. 2017;180:160-71.

86. Helaly AA, Goda Y, AbdEIRehim AS, Mohamed AA, ElZeiny OAH. Effect of polyethylene mulching type on the growth, yield and fruits quality of physalis pubescens. Adv Plants Agric Res. 2017. https://doi.org/10.15406/ apar.2017.06.00229.
87. Pandey S, Tewari GS, Singh J, Rajpurohit D, Kumar G. Efficacy of Mulches on Soil Modifications, Growth, Production and Quality of Strawberry (Fragaria x ananassa Duch). Adv Plants Agric Res. 2016;7:813-20.

88. Malik A, Shakir AS, Khan MJ, Naveedullah M, Latif M, Ajmal M, Ahmad S. Effects of different mulching techniques on sugar beet performance under semi-arid subtropical climatic conditions. Pakistan J Bot. 2018:50:1219-24

89. Ram RS, Rajbir S, Dinesh S, Ram KG. Influence of row covers and mulching interaction on leaf physiology, fruit yield and albinism incidence in 'Sweet Charlie'strawberry (Fragaria x ananassa Duch). Fruits. 2008;63:103-10.

90. Mitchell J, Summers C, McGriffen M, Aslan J and Stapleton J. Mulches in California vegetable crop production. Publ. by ANR Publ. 2002; United States Am.

91. Baiyeri M, Ahmed K, Echezona BC. Effect of coloured polyethylene mulch and harvesting stage on growth and yield of industrial sugarcane in Nigeria. African J Biotechnol. 2013;12:1078-83.

92. Fortier J-M. The market gardener: A successful grower's handbook for smallscale or- ganic farming. Gabriola Island: Canada New Soc. Publ; 2014.

93. Davis JM. Comparsion of mulching for fresh market basil production. HortScience. 1994;29:267-8.

94. Kasirajan S, Ngouajio M. Polyethylene and biodegradable mulches for agricultural applications: a review. Agron Sustain Dev. 2012;32:501-29.

95. Lamont WJ. Plastics: modifying the microclimate for the production of vegetable crops. Horttechnology. 2005;15:477-81.

96. Farias-Larios J, Orozco-Santos M. Effect of polyethylene mulch colour on aphid populations, soil temperature, fruit quality and yield of watermelon under tropical conditions. and Horticultural Science,. New Zealand J Crop. 1997; 25:369-374

97. Dickerson GW. Commercial vegetable production with plastic mulches. Cooperative Extension Service: College of Agriculture and Home Economics, New Mexico State University; 2002.

98. Brown JE, Dangler JM, Woods FM, Tilt KM, Henshaw MD, Griffey WA, West MS. Delay in Mosaic Virus Onset and Aphid Vector Reduction in Summer Squash Grown on Reflective Mulches. HortScience. 2019;28:895-6.

99. Summers CG, Mitchell JP, Stapleton JJ. Management of Aphid-Borne Viruses and Bemisia argentifolii (Homoptera: aleyrodidae) in Zucchini Squash by Using Uv Reflective Plastic and Wheat Straw Mulches. Environ Entomol. 2004:33:1447-57.

100. Brown SL, Brown JE. Steve L. Brown, James E. Brown. 1992; 2. 2:208-211.

101. Astner AF, Hayes DG, O'Neill HO, Evans BR, Pingali SV, Urban VS, Young TM. Mechanical formation of micro- and nano-plastic materials for environmental studies in agricultural ecosystems. Sci Total Env. 2019;685:1097-106.

102. Scheurer M, Bigalke M. Microplastics in Swiss Floodplain Soils. Environ Sci Technol. 2018;52:3591-8.

103. Von Moos N, Burkhardt-Holm P, Kohler A. Uptake and Effects of Microplastics on Cells and Tissue of the Blue Mussel Mytilus edulis L. after an Experimental Exposure. Environ Sci Technol. 2012; 46:11327-11335.

104. Huang Y, Zhao YR, Wang J, Zhang MJ, Jia WQ, Qin X. LDPE microplastic films alter microbial community composition and enzymatic activities in soil. Environ Pollt. 2019;254:112983.

105. De Souza MacHado, Anderson Abel Lau, Chung Wai Till, Jennifer Kloas, Werner Lehmann, Anika Becker, Roland Rillig, Matthias C. Impacts of Microplastics on the Soil Biophysical Environment. Environ Sci Technol. 2018;52:9656-9665.

106. Boots B, Russell CW, Green DS. Effects of Microplastics in Soil Ecosystems: above and Below Ground. Environ Sci Technol. 2019;53:11496-506.

107. Sideman RG. Performance of Sweetpotato Cultivars Grown in Using Biodegradable Black Plastic Mulch New Hampshire. 2015;25:412-6.

108. Chae Y, An YJ. Current research trends on plastic pollution and ecological impacts on the soil ecosystem: a review. Environ Pollut. 2018;240:387-95.

\section{Publisher's Note}

Springer Nature remains neutral with regard to jurisdictional claims in published maps and institutional affiliations. 